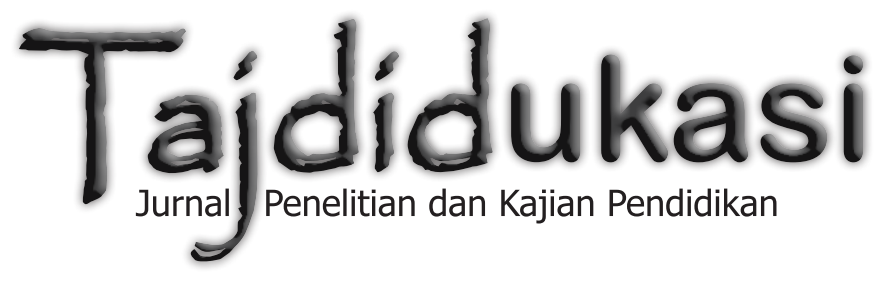




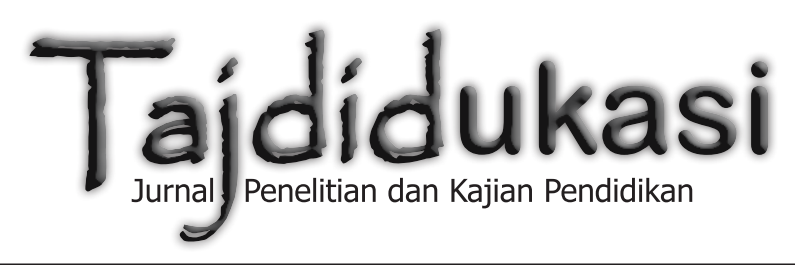

Volume VIII, No. 2, Juli 2018

ISSN: 1979-6943

Tajdidukasi: Jurnal Penelitian dan Kajian Pendidikan merupakan jurnal Penelitian dan Kajian Pendidikan yang berisi Penelitian Tindakan Kelas (PTK) dan Penelitian Tindakan Sekolah (PTS) serta Kajian Pendidikan interdisipliner di Perguruan Tinggi yang diterbitkan Majelis Pendidikan Dasar dan Menengah Pimpinan Wilayah Muhammadiyah Daerah Istimewa Yogyakarta. Artikel hasil PTK dan PTS serta kajian pemikiran pendidikan ditulis oleh para Guru dan Kepala Sekolah serta Dosen dalam mengujicobakan metode dan strategi pembelajaran untuk meningkatkan kualitas pendidikan baik SD/MI, SMP/MTs dan SMA/MA/SMK serta Perguruan Tinggi. Artikel PTK dan PTS fokus pada mata pelajaran di sekolah/madrasah, seperti Ilmu Pengetahuan Alam (IPA), Imu Pengetahuan Sosial (IPS), Matematika, Fisika, Kimia, bahkan teknik, seperti Teknik Mesin, Elektro, Informatika dan lain sebagainya. Sementara itu, artikel Kajian Pendidikan merupakan penelitian interdisipliner dan multidisipliner yang dilakukan Dosen di Perguruan Tinggi terhadap khasanah keIslaman.

Tajdidukasi: Jurnal Penelitian dan Kajian Pendidikan adalah jurnal terbuka yang versi softfile-nya bisa dibaca dan diakses secara gratis, sementara versi print out/ hardcopy dapat diperoleh dengan menghubungi distributor di alamat serial tajdidukasi.ac.id. Sof-file keseluruhan artikel yang diterbitkan dapat diakses melalui Tajdidukasi Open Access Juornal di www.dikdasmenpwmdiy.or.id

Pimpinan Editor
Suyadi, Universitas Ahmad Dahlan (UAD) Yogyakarta, Indonesia

Anggota Editor

Arif Budi Raharjo, Universitas Muhammadiyah Yogyakarta (UMY), Indonesia

Achmad Muhammad, UIN Sunan Kalijaga Yogyakarta, Indonesia

Hendro Widodo, Universitas Ahmad Dahlan (UAD) Yogyakarta

Mundzirin Yusuf, UIN Sunan Kalijaga Yogyakarta, Indonesia

Sumedi, UIN Sunan Kalijaga Yogyakarta, Indonesia

Sukamto, Universitas Muhammadiyah Yogyakarta (UMY), Indonesia

Sumarsono, UIN Sunan Kalijaga Yogyakarta Indonesia

Sarjilah (Lembaga Penjaminan Mutu Pendidikan) Yogyakarta

Fathur Rahman, M.Si., Universitas Negeri Yogyakarta (UNY) Indonesia

\section{Editor Pelaksana}

Suryanto, Universitas Muhammadiyah Yogyakarta (UMY), Indonesia

Suyatno, Universitas Ahmad Dahlan (UAD) Yogyakarta

Farid Setiawan, Universitas Ahmad Dahlan (UAD) Yogyakarta

Alamat Redaksi:

Kantor Majelis Pendidikan Dasar dan Menengah Pimpinan

Wilayah Muhammadiyah D.I. Yogyakarta

J1. Gedongkuning No. 130B Yogyakarta

Kode Pos : 55171

Telephone : (0274) 377078

Facsimile : (0274) 371718

Website : www.dikdasmenpwmdiy.or.id

E-Mail : tajdidukasi@dikdasmenpwmdiy.or.id 


\title{
"PENINGKATAN KEAKTIFAN DAN HASIL BELAJAR SISWA DENGAN METODE INDEX CARD MATCH PADA PEMBELAJARAN IPA"
}

\author{
Amin Rosadi \\ SMP Muhammadiyah 1 Depok \\ Email: afsarrosi1722@gmail.com
}

\begin{abstract}
Abstrak
Penelitian ini bertujuan untuk mengetahui peningkatan keaktifan dan hasil belajar siswa pada mata pelajaran IPA Kelas VIII D dengan metode Indeks Card Match. Metode yang digunakan dalam penelitian ini adalah Penelitian Tindakan Kelas (PTK). Penelitian ini melalui tahapan perencanaan, pelaksanaan, observasi, dan refleksi yang dilakukan pada setiap siklus. Penelitian ini dilaksanakan di SMP Muhammadiyah 1 Depok dengan subyek penelitian kelas VIII D tahun ajaran 2017/2018 dengan jumlah 30 siswa. Hasil penelitian menunjukkan bahwa metode pembelajaran Index Card Match dapat meningkatkan keaktifan dan hasil belajar siswa mata pelajaran IPA pada materi Hukum Newton, Usaha dan energi. Hal ini menunjukkan keaktifan belajar siswa yang meliputi; Visual activities: membaca sumber belajar, Oral activities : bertanya, Listening activities: mendengarkan uraian, Writing activities: menulis konsep penting, Motor activities: bergerak atau berpindah tempat, Mental activities : memecahkan masalah dalam kelompok, Emosional activities: melakukan presentasi di depan teman-temannya dapat meningkat dari satu siklus ke siklus berikutnya. Pra siklus 30,47\% kemudian siklus I sebesar 59,28\% dan siklus II menjadi 84,26\% . Pada hasil penelitian selanjutnya Hasil belajar juga mengalami peningkatan dari siklus I yang tuntas sebesar $46 \%$ atau 14 dari 30 siswa dan di siklus II sebesar $83,3 \%$ atau 25 dari 30 .
\end{abstract}

Kata kunci : Indeks card match, keaktifan belajar, hasil belajar

\section{A. PENDAHULUAN}

Dalam skala global pendidikan Indonesia tertinggal jauh dengan negaranegara lain, hal ini bisa dilihat dalam peringkat ujian PISA (Program For International Student Assesment) yaitu penilaian tingkat dunia yang menguji performa akademik sains, membaca dan matematika anak-anak sekolah berusia 15 tahun setingkat SMP yang diadakan oleh organisasi untuk kerjasama dan pengembangan ekonomi, Organization For Economic Cooperation And
Development (OECD) menempatkan Indonesia pada bidang sains tahun 2012 peringkat 64 dari 65 negara kemudian meningkat pada tahun 2015 meningkat yaitu 62 dari 70 negara, tetapi tetap menempatkan negara Indonesia pada papan bawah. (www.kemdikbud.com). Hal ini menjadi sebuah pertanyaan besar, bagaimana sebenarnya pelaksanaan pendidikan yang terjadi di indonesia?

Proses pendidikan idealnya dapat meningkatkan keaktifan dan prestasi belajar siswa. Hal ini sesuai dengan tujuan 
pendidikan nasional bahwa pendidikan harus bisa mengembangkan minat dan kemampuan siswa agar dapat membawa martabat bangsa (UU Sisdiknas No 20 tahun 2003). Tujuan tersebut sejalan dengan tuntutan pendidikan abad 21 yang telah membawa banyak perubahan yang signifikan dalam segala sendi kehidupan, salah satunya dunia pekerjaan Menurut (NEA) National Education Association (dalam Widodo,2017), tren pekerjaan yang membutuhkan keterampilan rutin menurun sementara pekerjaan yang membutuhkan keterampilan nonrutin, analitis, dan komunikasi secara interaktif mengalami peningkatan

Siswa harus dibekali penguasaan $21^{\text {st }}$ century sklills yang dapat dicapai melalui proses pembelajaran menurut Rotherdam \& Willingham (dalam widodo,2017): kesuksesan seorang siswa tergantung pada kecakapan abad 21 . Menurut NEA (2002) Ada 18 macam $21^{\text {st }}$ Century Skills yang perlu dibekalkan pada siswa.Aspek Learning and Innovation Skills-4Cs: critical thinking (berpikir kritis), communication (komunikasi), collaboration (kolaborasi/kerjasama), creativity (kreatifitas) Merupakan aspek keterampilan paling penting yang harus dikuasai siswa pada jenjang pendidikan dasar sampai menengah. Pada hakikatnya IPA merupakan produk dan proses, dengan demikian pembelajaran IPA menjadi cara yang baik untuk dapat mengembangkan 4Cs Skills. Melalui berbagai pendekatan yang sesuai, pembelajaran IPA diharapkan dapat mendorong siswa untuk melek IPA dan teknologi, mampu berpikir logis dan kritis, berargumentasi secara rasional, serta bertindak secara komprehensif dalam memecahkan berbagai persoalan pada kehidupan nyata.

Proses pembelajaran di kelas menjadi sangat penting dalam mengembangkan ketrampilan abad 21 bagi siswa. Pada kelas VIII D pembelajaran IPA masih tidak menarik pada siswa, hal ini dapat dilihat banyak siswa yang tidak memperhatikan dalam pelajaran ada yang tidur, ada yang ngobrol sendiri, dan sebagian kecil yang memperhatikan sehingga keaktifan mereka sangat kurang dalam kelas. Kurang perhatiannya siswa dalam pembelajaran juga berimplikasi pada hasil belajar dimana masih banyak siswa yang tidak lolos KKM yaitu 75 dan dari 30 anak hampir semua tidak lolos pada Penilaian tengah semester (PTS) tahun 2017. Hal ini menunjukkan bahwa masih rendahnya pembelajaran IPA di dalam kelas, dimana guru tidak merangsang pembelajaran dengan menyenangkan dan membuat lebih sederhana materi yang ada. Keadaan ini menjadi masalah bagi guru, karena pembelajaran IPA yang berlangsung diharapkan bisa diserap dan dimaknai sebagai ilmu yang menekankan tidak hanya pada hasil tetapi juga proses yang berlangsung.

Berdasarkan permasalahan tersebut di atas, diperlukan upaya perbaikan proses pembelajaran IPA dengan menggunakan metode pembelajaran yang dapat meningkatkan keaktifan dan prestasi belajar siswa. Salah satu metode pem- 
belajaran aktif adalah metode Index Card Match. Metode pembelajaran ini diharapkan dapat memberikan pengaruh yang positif terhadap keaktifan dan hasil belajar IPA siswa sesuai dengan yang diharapkan, yaitu membuat siswa di kelas VIII D dapat aktif secara positif dan mampu meningkat hasil belajar mereka.

\section{Keaktifan Siswa}

Keaktifan siswa adalah salah satu ciri bahwa kelas yang sedang mengadakan proses pembelajaran itu hidup. Keaktifan berasal dari kata dasar aktif. Aktif dalam Kamus Bahasa Indonesia Kontemporer diartikan sebagai selalu berusaha, bekerja, atau belajar dengan sungguh-sungguh supaya mendapat kemajuan atau prestasi yang gemilang (Peter salim:1991:34) Dalam pendapat (Sriyono:1992:6) kegiatan keaktifan siswa melibatkan bebarapa aspek baik secara fisik, mental, emosional maupun intelektual artinya dalam proses pembelajaran siswa mengambil peran yang besar untuk secara aktif dalam memahami informasi dan ilmu yang akan dipelajari sehingga tujuan pembelajaran akan tercapai. Hal ini sesuai dengan kurikulum 2006 atau (Kurikulum tingkat satuan pendidikan) KTSP juga mengamanatkan untuk merubah proses pembelajaran dari yang berpusat pada guru (Teacher Centered) menjadi berpusat pada siswa (Student Centered).

Konsep belajar yang aktif siswa tidak dianggap sebagai individu yang pasif yang hanya sebagai penerima informasi, akan tetapi dipandang sebagai organisme yang aktif yang memiliki potensi untuk berkembang, yakni mereka mempunyai potensi dan kemampuan. Menurut Paul B. Dierich (dalam Sardiman:1996:100), klasifikasi keaktifan belajar siswa sebagai berikut:

1. Visual activities: membaca, memperhatikan gambar demonstrasi, percobaan, pekerjaan orang lain.

2. Oral activities: menyatakan, merumuskan, bertanya, memberi saran, mengeluarkan pendapat, mengadakan wawancara, diskusi.

3. Listening activities: mendengarkan uraian, mendengarkan percakapan, mendengarkan diskusi

4. Writing activities: menulis laporan, menulis cerita, menyalin

5. Drawing activities: menggambar, membuat grafik, membuat diagram

6. Motor activities: melakukan percobaan, membuat konstruksi

7. Mental activities: menanggapi, mengingat, memecahkan masalah, menganalisis, mengambil kesimpulan, dan melihat hubungan

8. Emosional activities: menaruh minat, merasa bosan, gembira, tenang.

\section{Metode Index Card Match}

Adalah cara belajar aktif dan menyenangkan untuk meninjau ulang mata pelajaran. Cara ini memungkinkan siswa untuk berpasangan dan memberi pertanyaan kuis pada temannya.(Mel Siberman:2013:250)

Prosedur:

1. Pada kartu index yang terpisah, 
tulislah pertanyaan tentang apapun yang diajarkan dikelas. Buatlah kartu pertanyaan dengan jumlah yang sama dengan setengah jumlah siswa

2. Pada kartu yang terpisah tulislah jawaban atas masing-masing pertanyaan itu

3. Campurkan dua kumpulan kartu itu dan kocoklah beberapa kali agar tercampur aduk

4. Berikan satu kartu untuk siswa, jelaskan bahwa ini merupakan latihan pencocokan. Sebagian siswa mendapatkan pertanyaan tinjauan dan sebagian lain mendapatkan kartu jawabannya

5. Perintahkan siswa untuk mencari kartu pasangan mereka. Bila sudah terbentuk pasangan, perintahkan siswa yang berpasangan itu untuk mencari tempat duduk bersama (katakan kepada mereka untuk tidak mengungkapkan kepada pasangan lain apa yang ada dikartu mereka)

6. Bila semua pasangan yang cocok telah duduk bersama, perintahkan tiap pasangan untuk memberikan kuis kepada siswa yang lain dan membaca keras-keras pertanyaan mereka dan menantang siswa lain untuk memberikan jawabannya.

\section{B. METODE PENELITIAN}

Penelitian ini dilaksanakan di kelas VIII D SMP Muhammadiyah 1 Depok. Waktu penelitian dilaksanakan pada pembelajaran semester genap Tahun Ajaran 2017/2018 tanggal 2 Januari -
28 Februari 2018. Subyek penelitian ini adalah siswa kelas VIII D SMP Muhammadiyah 1 Depok tahun ajaran 2017/2018, yaitu 30 siswa yang terdiri dari 13 putri dan 17 putra, dan obyek penelitian ini adalah Pembelajaran kooperatif mata pelajaran IPA dengan metode Index Card Match materi Hukum Newton.

\section{Desain Penelitian}

Jenis Penelitian ini adalah penelitian PTK yang dilakukan secara kolaboratif. Dalam penelitian kolaboratif pihak yang melakukan tindakan adalah guru itu sendiri sedangkan yang diminta melakukan pengamatan terhadap berlangsungnya proses tindakan adalah peneliti (Suharsimi Arikunto,2008;16) menurut Kemmis dan Taggart ada beberapa tahapan dalam penelitian ini (Rohiati Wiratmaja,2005;66), yaitu:

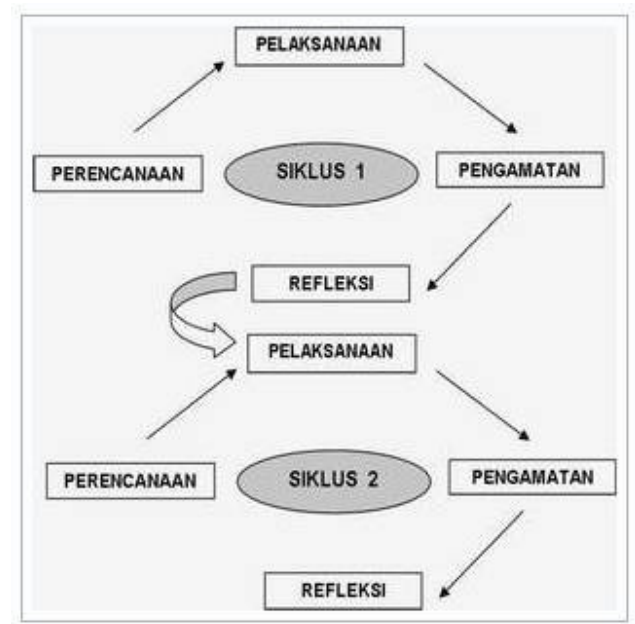

Gambar 1. Desain Penelitian Tinadakan Kelas 
Dalam penelitian ini direncanakan terdapat 2 siklus. Siklus dihentikan apabila kondisi kelas sudah stabil hal ini guru sudah mampu menguasai ketrampilan belajar yang baru dan siswa sudah terbiasa dengan metode index card match, serta data yang ditampilkan oleh siswa sudah jenuh, dalam arti sudah ada peningkatan keaktifan dan prestasi belajar siswa (Rochiati Wiraadmaja,2005; 103)

Kriteria keberhasilan tindakan

1. Aktifitas Siswa

Lembar observasi digunakan untuk mengamati aktifitas siswa di dalam kelas selama proses pembelajaran IPA berlangsung menggunakan metode index card match. (Suharsimi:2006) aktifitas siswa akan dianalisis dengan melihat jumlah indikator- indikator yang terpenuhi dari butir-butir aktifitas siswa dengan menghitung prosentase nilai yang dicapai oleh masing-masing siswa dengan rumus:

Nilai $=\underline{\text { Jumlah skor diperoleh }} \times 100 \%$ Jumlah skor maksimal

Ketuntasan klasikal siswa (\%) = Jumlah nilai peroleh siswa $\times 100 \%$ Jumlah maksimal seluruh nilai

Kemudian dideskripsikan berdasarkan kriteria
a. kurang $(0 \%-25 \%)$,
b. sedang $(26 \%-50 \%)$,
c. baik $(51 \%-75 \%)$,
d. dan baik sekali (76\% $-100 \%)$.
Indikator keberhasilan untuk ak- tifitas siswa adalah apabila jumlah

indikator-indikator yang terpenuhi dari butir-butir aktivitas siswa mencapai kriteria baik dan baik sekali untuk masing-masing siswa dan ketuntasan klasikal seluruh siswa mencapai $70 \%$.

2. Hasil belajar

Pemberian tes dilakukan secara individu kepada masing-masing siswa untuk mengetahui ketuntasan hasil belajar siswa. Nilai tes individu ini akan dihitung dengan cara menghitung jumlah jawaban benar dibagi jumlah soal kali seratus persen.

Nilai $=$

Jumlah nilai jawaban benar x $100 \%$ Jumlah seluruh soal

Ketuntasan klasikal dihitung dengan:

Ketuntasan Klasikal = Jumlah siswa tuntas $\times 100 \%$ Jumlah seluruh siswa

Siswa yang memperoleh nilai lebih besar/ sama dengan 75 dinyatakan tuntas. Indikator keberhasilan untuk hasil belajar siswa secara keseluruhan adalah apabila telah mencapai ketuntasan belajar klasikal sebesar $80 \%$ dari jumlah seluruh siswa. Artinya dari sejumlah sampel penelitian 30 siswa yang telah mencapai nilai 75 sebanyak 24 siswa.

\section{PEMbahasan}

\section{Deskripsi Awal}

Tujuan dari penelitian ini adalah untuk meningkatkan keaktifan dan hasil belajar mata pelajaran IPA. Peneliti memaparkan hasil dari penelitian 
berdasarkan langkah-langkah dalam pelaksanaaan penelitian, dari tahap awal perencanaan, tindakan, observasi dan tahap akhir yaitu refleksi.

Penelitian ini dilaksanakan di SMP Muhammadiyah 1 Depok yang beralamat di Dusun Stan, Maguwoharjo, Depok, Kabupaten Sleman. Sebagai salah satu amal usaha Muhammadiyah di wilayah Depok, maka SMP Muhammadiyah 1 Depok menjadi salah satu pilihan dari beberapa sekolah di wilayah Depok yang memberikan pelayanan pendidikan berkualitas. Sekolah yang berdiri tahun 1968 ini memiliki letak yang sangat strategis dekat dengan pasar Stan, dan stadion Maguwoharjo yang merupakan daerah ramai karena sebagai jalur alternatife ke daerah Ngemplak, Ngaglik dan Kalasan dengan jumlah siswa 385 siswa 12 rombongan kelas.

Sekolah ini terdiri dari 12 kelas tersebut yaitu VII, VIII dan IX yang masing-masing jenjang kelas terdiri dari Kelas A,B, C dan D. Sekolah ini dipimpin oleh Bp. Abdulah Mukti, S.Pd.I sejak tahun 2009 sampai tahun 2018 sekarang, dengan tenaga pendidik berjumlah 28 orang dan 5 karyawan. pada hal ini peneliti menggunakan kelas VIII D sebagai subyek penelitian. Berikut ini merupakan tahap deskripsi awal tindakan, yaitu:

\section{Perencanaan Pra Siklus}

Penelitian awal dilakukan untuk dapat dijadikan acuan dalam melaksanakan peneltian tindakan kelas. Penelitian ini di laksanakan di kelas VIII D SMP
Muhammadiyah 1 Depok dengan materi gaya. Peneliti ingin mengetahui lebih jelas tentang keaktifan belajar siswa kelas VIII D dalam mengikuti pembelajaran IPA dalam hal ini dengan materi Gaya.

\section{Pelaksanaan Pra Siklus}

Guru masuk ke kelas VIII D untuk memberikan materi tentang gaya. Guru memberikan beberapa contoh gaya yang terjadi dalam kehidupan seharihari. Siswa memperhatikan dengan baik penjelasan dari guru dan diminta untuk memberikan pendapat mengenai contoh gaya dalam kehidupan sehari-hari. Dari kesempatan yang diberikan hanya ada beberapa siswa yang merespon pertanyaan dari guru. Sedangkan siswa yang lain juga masih sibuk sendiri.

\section{Analisis Per Siklus}

\section{Siklus 1}

a. Tahap Perencanaan

Pembelajaran IPA dikelas VIII D menunjukkan bahwa siswa masih kurang dalam keaktifan belajar yang berbanding lurus dengan hasil belajar mereka yang rendah. Oleh karena itu penulis menggunakan metode indek card match untuk dapat meningkatkan keaktifan belajar dan hasil belajar siswa.

Peneliti yang juga guru membuat perencanaan pembelajaran yaitu RPP dengan materi hukum Newton yang merupakan lanjutan dari materi sebelumnya yaitu gaya. Peneliti tidak sendiri dalam melaksanakan penelitian dalam hal ini berkolaborasi dengan dosen 
pembimbing, yaitu Ibu Enung Hasanah untuk ikut mengamati pembelajaran yang siklus 1 pertemuan pertama dan Bp. Imron Wafudrahman selaku teman sejawat.

b. Tahap Tindakan

b.1 Pertemuan Pertama

Pembelajaran IPA Kelas VIII D SMP Muhammadiyah 1 Depok dilaksanakan pada hari Senin 22 Januari 2018 pada jam 10.00 - 11.20 (jam ke-5 dan 6) dengan materi Hukum I dan II Newton. Adapun pelaksanaannya meliputi:

1) Membuka pelajaran dengan doa, memberikan salam dan mengecek presensi kehadiran siswa

2) Motivasi dan apersepsi :

a) Meminta salah satu siswa untuk maju ke depan dan mendemontrasikan untuk menarik penghapus yang ada di atas kertas dengan cepat dan pelan? Apa yang terjadi?

b) Meminta siswa yang lain untuk mendemonstrasikan menjatuhkan kertas dan penghapus dari ketinggian yang sama, mana yang lebih dulu sampai tanah?

c) Siapakah itu Newton?

3) Menyampaikan tujuan pembelajaran dan metode pembelajaran index card match

4) Guru memberikan pembelajaran materi hukum I dan II Newton menggunakan simulasi melalui komputer

5) Guru menyiapkan potongan kartu yang dicampur berisi 15 pertanyaan dan 15 jawaban

6) Guru menginstruksikan siswa mengambil satu kartu serta menjelaskan bahwa ini adalah aktivitas berpasangan, setengah mendapatkan pertanyaan dan setengah yang lain jawaban.

7) Guru menginstruksikan siswa untuk menemukan pasangan mereka kemudian duduk berdekatan.

8) Guru memerintahkan setiap pasangan yang untuk membacakan pertanyaan dengan keras dan menguji pasangan siswa yang lain untuk menjawab

9) Guru memberi klarifikasi terhadap jawaban dan pendapat siswa tentang hukum I dan II Newton

10) Guru menyimpulkan materi hasil belajar

11) Guru melakukan tes lisan untuk mengetahui daya serap

12) Guru menutup pelajaran dengan salam

Pada pembelajaran metode Index Card Match setelah siswa menerima kartu kemudian mereka mencocokkan dengan mencari pasangan yang tepat antara pertanyaan dan jawaban. Setelah mereka mencocokkan kartu pertanyaan dan jawaban siswa berdiri di depan kelas dengan pasangannya masing-masing kemudian mereka yang punya jawaban membacakan dengan keras pertanyaan dan siswa yang lain diharapkan menjawab pertanyaan itu, dengan siapa yang memberi isyarat maka dia yang menjawab terlebih dahulu yakni dengan sistem rebutan. 
Berdasarkan hasil tabel perolehan nilai siswa tentang proses pembelajaran dengan metode Index Card Match bahwa terdapat 16 siswa yang berpasangan benar, 4 salah berpasangan dan 5 siswa tidak memperoleh pasangan. Berdasarkan tabel hasil keaktifan siswa dengan metode pembelajaran Index Card Match keaktifan rata-rata belajar siswa pada pembelajaran siklus I pertemuan pertama adalah $47,61 \%$.

\section{b.2 Pertemuan kedua}

Pembelajaran pada pertemuan kedua dilaksanakan pada hari Rabu 24 Januari 2018 pada jam 10.40-11.20 di kelas 8D. Pada pertemuan kedua masih melanjutkan materi tentang hukum II Newton dan dilanjutkan hukum III Newton.

Adapun kegiatan dalam Pertemuan kedua yaitu:

1. Membuka pelajaran dengan doa, memberikan salam dan mengecek presensi kehadiran siswa

2. Motivasi dan apersepsi :

a. Meminta salah satu siswa untuk mendorong tembok? Apa yang terjadi?

b. Guru membawa roket air dan meminta anak menjelaskan cara kerjanya?

3. Menyampaikan tujuan pembelajaran dan metode pembelajaran index card match

4. Guru memberikan pembelajaran awal materi hukum II dan III Newton

5. Guru menyiapkan potongan kartu yang dicampur berisi 15 pertanyaan dan 15 jawaban

6. Guru menginstruksikan siswa mengambil satu kartu serta menjelaskan bahwa ini adalah aktivitas berpasangan, setengah mendapatkan pertanyaan dan setengah yang lain jawaban.

7. Guru menginstruksikan siswa untuk menemukan pasangan mereka kemudian duduk berdekatan.

8. Guru memerintahkan setiap pasangan yang untuk membacakan pertanyaan dengan keras dan menguji pasangan siswa yang lain untuk menjawab

9. Guru memberi klarifikasi terhadap jawaban dan pendapat siswa tentang hukum II dan III Newton

10. Guru menyimpulkan materi hasil belajar

11. Guru melakukan tes lisan untuk mengetahui daya serap

12. Guru menjelaskan untuk mempersiapkan pertemuan selanjutnya yaitu ulangan harian.

13. Guru kemudian menutup pelajaran dengan salam

Berdasarkan hasil perolehan nilai siswa tentang proses pembelajaran dengan metode Index Card Match bahwa terdapat 26 siswa yang berpasangan benar, 2 salah berpasangan dan 2 siswa tidak memperoleh pasangan. Berdasarkan hasil keaktifan siswa dengan metode pembelajaran Index Card Match keaktifan rata-rata belajar siswa pada pembelajaran siklus I pertemuan kedua adalah $70,95 \%$. 
c. Tahap Observasi

Pada saat melaksanakan pembelajaran di siklus I ada lembar observasi yang digunakan untuk merekam proses pembelajaran yang berlangsung, ada 2 pihak yang dijadikan sudut pandang yaitu guru dan siswa.

\section{1) Observasi guru}

Guru masih mendominasi pembelajaran terutama pada pertemuan pertama, hal ini dikarenakan guru masih terbawa suasana seperti pembelajaran sebelum menggunakan metode indek card match. Pelaksanaan pembelajaran sesuai dengan perencanaan juga sudah dilakukan oleh guru. Mulai dari tahap apersepsi, kegiatan inti yang meliputi eksplorasi, elaborasi, dan konfirmasi. Kemudian diakhiri dengan kegiatan penutup.

Peran guru untuk memastikan bahwa siswa sudah mencatat konsep penting yang sudah diterangkan juga tidak dilakukan, sehingga masih banyak siswa yang tidak mencatat konsep penting. Dan untuk mengetahui daya serap siswa guru harusnya memberikan pertanyaan untuk mereview kembali apa yang sudah dipelajari.

\section{2) Observasi Siswa}

Pembelajaran menggunakan metode index card match bertujuan untuk meningkatkan keaktifan belajar siswa belum mencapai hasil maksimal. Pada pertemuan pertama siswa masih banyak yang tidak membawa buku paket yang merupakan salah satu sumber belajar. Kemudian masih banyak siswa yang tidak mau mencatat konsep penting tentang materi yang disampaikan dalam hal ini hukum Newton I, II dan III.

Siswa mulai memahami pembelajaran dengan metode indek card match sehingga pada pertemuan kedua pembelajaran sudah mulai lebih lancar dan tidak begitu riuh. Beberapa aspek seperti membawa buku paket, mendengarkan teman saat presentasi, bergerak atau berpindah tempat saat permainan berlangsung bisa dimaksimalkan akan tetapi untuk aspek keaktifan belajar seperti bertanya atau berpendapat, melakukan presentasi, dan memecahkan masalah dalam kelompok masih perlu untuk diperbaiki lagi.

d. Tahap Refleksi

Pembelajaran yang telah dilakukan pada siklus I, masih banyak kekurangan baik dalam hal perencanaan maupun dalam pelaksanaannya, sehingga ada beberapa catatan untuk siklus I, diantaranya:

1) RPP yang masih bersifat Teacher Centered, masih berpusat pada guru

2) Banyak siswa yang belum memperhatikan dan cenderung pasif menunggu informasi dari guru

3) Ada beberapa siswa yang belum membawa buku paket yang merupakan salah satu sumber belajar

4) Pada satu jam pertama guru masih mendominasi pembelajaran meskipun apersepsi yang diberikan sudah cukup baik untuk memberikan pengantar kepada siswa memahami materi hukum I dan II Newton setelah 
itu guru memberikan kesempatan siswa untuk memberikan pendapatnya. Pembelajaran awal diberikan apersepsi dengan mendemonstrasikan menarik penghapus diatas meja secara cepat akan tetapi penghapus tidak terjatuh serta menjatuhkan kertas dan penghapus dari ketinggian yang sama secara bersamaan untuk melihat benda yang lebih dahulu jatuh ke lantai.

5) Guru tidak mengingatkan siswa untuk mencatat konsep dasar hukum I dan II Newton

6) Ada tiga siswa yang sama sekali tidak menunjukkan reaksi

7) Pembelajaran Index Card Match masih belum teratur ketika semua siswa berada di depan kelas ada 8 pasang siswa mendapatkan pasangan benar, kemudian ada 3 pasangan siswa salah dan 5 siswa tidak mendapatkan pasangan.

Pada pertemuan selanjutnya peneliti mencoba menata kembali langkah pembelajaran metode Index Card Match yaitu siswa yang sudah mendapatkan pasangan kemudian duduk dengan pasangannya sedangkan yang tidak mendapatkan pasangan untuk berdiri di depan kelas yang bertujuan agar pembelajaran terkendali dengan baik dan dapat meningkatkan keaktifan siswa.

\section{Siklus II}

a. Tahap Perencanaan

Pembelajaran pada Siklus I yang sudah dilaksanakan oleh penulis, mem- berikan banyak pengalaman bagi penulis untuk memperbaiki pembelajaran disiklus yang kedua ini. Hal ini dilaksanakan karena pada siklus I ini belum mencapai standar yaitu $76 \%$ untuk peningkatan keaktifan belajar siswa dan hasil belajar siswa berupa ulangan harian yang menunjukkan belum mencapai angka $76 \%$ atau lebih.

Pada tahap perencanaan penulis membuat perangkat pembelajaran yang mengakomodir kegiatan siswa lebih banyak dibandingkan guru. Sehingga mulai dari apersepsi sampai siswa bisa berfikir dan memperoleh pengalaman belajar yang bermakna. Pembuatan RPP dan instrumen Lembar observasi untuk melihat apakah guru dan siswa sudah sesuai dengan aturan yang ada.

b. Tahap Pelaksanaan

1) Pertemuan pertama

Siklus kedua dilanjutkan karena di siklus I siswa belum mencapai keaktifan di kelas dengan standar $75 \%$ yakni masih 70,95\% dengan materi usaha dan energi. Kegiatan belajar mengajar ini berlangsung pada hari senin, 12 Februari 2018 di kelas VIII D Jam ke 5 dan 6.

1) Memberikan salam dan mengecek presensi kehadiran siswa

2) Guru menjelaskan tentang tujuan dan metode pembelajaran Index Card Match

3) apersepsi : meminta salah satu siswa maju kedepan untuk membakar kertas dan uang yang sudah diberi alkohol dan membandingkannya 
4) Siswa mengamati demonstrasi uang yang dibakar

5) Siswa mengamati alat-alat yang ada dikelas, seperti kipas angin, lampu, kemudian bel sekolah

6) Siswa membandingkan alat-alat seperti kipas angin, lampu, dan bel sekolah ternyata ada perubahan energi

7) Siswa menyatakan pendapat tentang perubahan bentuk energi

8) Siswa membandingkan teori dengan yang dilihat

9) Siswa menerima instruksi untuk pembagian kartu index

10) Siswa mencari pasangan untuk menjodohkan antara jawaban dan soal

11) Siswa duduk dibangku setelah mendapat pasangan yang tepat

12) Siswa yang akan memberi pertanyaan berdiri dan siswa yang lain menjawab

13) Siswa menyebutkan perubahan bentuk energi pada alat-alat di sekitarnya

14) Guru menanggapi siswa dan memberi informasi yang benar

15) Guru bersama siswa membuat rangkuman sesuai dengan tujuan pembelajaran

16) Guru memberikan nasehat untuk persiapan materi berikutnya

17) Guru menutup pelajaran dengan salam

Dalam mengemukakan pendapat masih ada beberapa kelemahan diantaranya hanya 15 siswa yang mau berpendapat dalam artian baru $50 \%$.
Pada kriteria keaktifan yaitu berani tampil di depan kelas hanya 13 siswa atau $43 \%$. Berdasarkan hasil tersebut menjadi bahan refleksi untuk pertemuan selanjutnya. Berdasarkan hasil keaktifan siswa dengan metode pembelajaran Index Card Match keaktifan rata-rata belajar siswa pada pembelajaran siklus I pertemuan kedua adalah $73,8 \%$

2) Pertemuan kedua

Pembelajaran Siklus II pertemuan kedua dilaksanakan pada hari Rabu 14 Februari 2018 di kelas 8 D SMP Muhammadiyah 1 Depok, dari refleksi pertemuan pertama maka penulis melakukan beberapa persiapan yang lebih baik untuk dapat meningkatkan keaktifan belajar siswa.

1. Memberikan salam dan mengecek presensi kehadiran siswa

2. Guru Menjelaskan tujuan dan metode pembelajaran Index Card Match

3. Meminta salah satu dari siswa untuk mendemonstrasikan mobil bertenaga balon

4. Siswa yang lain mengamati mobil yang dapat bergerak dengan tenaga balon

5. Siswa yang lain mengemukakan pendapat tentang mobil bertenaga balon

6. Siswa membandingka teori dengan praktik mobil bertenga balon

7. Siswa menuliskan rumus tentang energi kinetik

8. Siswa memperhatikan contoh kemudian diberi kesempatan untuk mengerjakan dengan teman sebangkunya 
9. Siswa menerima instruksi untuk pembagian kartu index dimana setiap siswa mengambil satu

10. Siswa mencari pasangan untuk mencari pasangan antara pertanyaan dan jawaban

11. Siswa yang sudah memperoleh pasangan kemudian duduk dibangku manapun dikelas

12. Meminta siswa untuk memberikan pertanyaan dengan keras dan menantang selain pasangannya untuk menjawab

13. Siswa bersama guru menyimpulkan tentang energi kinetik (gerak)

14. Siswa dan guru membuat rangkuman bersama

15. Guru menutup pelajaran dengan salam

Berdasarkan hasil tabel perolehan nilai siswa tentang proses pembelajaran dengan metode Index Card Match bahwa terdapat 26 siswa yang berpasangan benar, 4 salah berpasangan dan siswa tidak memperoleh pasangan tidak ada.

3) Pertemuan ketiga

Pembelajaran siklus II pada pertemuan ketiga dilaksanakan pada hari senin jam ke 5 dan 6 tanggal 19 februari 2018. Pada refleksi pertemuan kedua masih ada beberapa kekurangan yang belum terlaksana seperti keberanian tampil didepan kelas $53 \%$ dan memecahkan masalah dalam kelompok $70 \%$ maka penulis mendorong dan memotivasi siswa untuk bisa lebih banyak yang melakukan presentasi, yakni keberanian mengemukakan pendapat dan pemecahan masalah dalam kelompok yang nanti dalam permainan index card match bisa dimaksimalkan dengan banyak yang mendapatkan pasangan yang benar. Berikut beberapa langkah pembelajaran yang dilaksanakan di pertemuan ketiga:

1. Guru membuka dengan salam dan mengecek kehadiran siswa

2. Guru menjelaskan tujuan dan metode pembelajaran Index Card Match

3. Apersepsi: membandingkan bola diam di atas lantai dan bola pada ketinggian tertentu kemudian dijatuhkan

4. Siswa yang lain mengamati peristiwa bola yang dijatuhkan dengan bola yang diam di atas lantai.

5. Siswa diminta untuk memberikan pendapat mereka tentang demonstrasi bola

6. Siswa membandingkan antara teori energi potensial dengan praktik

7. Salah satu siswa maju ke depan menuliskan rumus energi potensial

8. Siswa memperhatikan contoh soal dengan teman sebangku

9. Siswa menerima instruksi untuk pembagian kartu index

10. Siswa mencari pasangan dalam waktu 3 menit

11. Siswa diminta untuk duduk sebangku bagi yang sesuai pasangan

12. Salah satu siswa berdiri membacakan keras pertanyaan dan siswa yang lain yang bukan pasangannya untuk bisa menjawab

13. Siswa bersama guru menyimpulkan tentang energi potensial dan usaha 
14. Guru mengingatkan untuk pertemuan selanjutnya adalah ulangan harian tentang energi

15. Guru menutup pelajaran dengan salam

Berdasarkan hasil keaktifan siswa dengan metode pembelajaran Index Card Match keaktifan rata-rata belajar siswa pada pembelajaran siklus II pertemuan ketiga adalah 93,3\%.

c. Tahap observasi

Observasi pada siklus kedua ini dilakukan tiga kali pertemuan, dimana setiap pertemuan difokuskan untuk melihat kegiatan guru dan siswa dalam pembelajaran dengan metode index card match, dengan disediakan lembar pengamatan maka guru dilihat apakah sudah sesuai dengan perencanaan saat dia tampil di depan kelas, sedangkan untuk siswa akan diamati apakah sudah masing-masing siswa dikelas VIII D mengikuti kegiatan pembelajaran dengan standar keaktifan belajar siswa yang meliputi 7 aspek.

\section{1) Guru}

Guru melaksanakan kegiatan pembelajaran sesuai dengan RPP yang sudah dibuat, guru sudah memeriksa siswa apakah mereka sudah mencatat atau belum konsep penting dalam materi energi. guru juga sudah mampu membuat siswa percaya diri sehingga mereka berani berpendapat dan mengajukan pertanyaan, terutama pada pertemuan kedua dan ketiga.

Daya serap siswa yang harusnya bisa diukur salah satunya dengan memberikan pertanyaan diakhir pada pertemuan kedua terlewatkan oleh guru, sehingga siswa dibiarkan begitu saja dalam mengambil kesimpulan. Begitu juga saat pertemuan pertama bahwa guru menjelaskan akan adanya ulangan harian, karena masih dipertemuan pertama sehingga ada yang kurang tepat dalam perencanaan.

2) Siswa

Kegiatan siswa disiklus yang kedua ini terbagi menjadi 3 kali pertemuan dengan materi energi dan usaha. mereka mulai menunjukkan keaktifan dalam belajar yang meliputi aspek membaca sumber belajar, menulis informasi penting, bergerak dan berpindah tempat, aspek bertanya, mendengarkan teman saat presentasi juga ikut mengalami peningkatan aspek memecahkan masalah dalam kelompok yang ditandai dengan semakin banyak pasangan yang benar maka mereka juga dianggap sudah bisa memecahkan masalah dalam kelompok dan untuk hal ini sebagian anak masih merasa kesulitan untuk pertanyaan yang berhitung dan menggunakan rumus,karena mereka sudah di ingatkan untuk bisa mencapai keaktifan belajar.

Aspek untuk berani tampil didepan kelas untuk presentasi dalam pembelajaran ini dapat dipahami tidak hanya saat bertanya atau mengemukakkan pendapat. Berani tampil di depan kelas bisa juga tercermin saat siswa membacakan dengan keras pertanyaan yang ada di dalam kartu yang mereka pegang, kemudian dengan antusias teman-teman 
yang ikut menjawab, karena ada penilaian untuk aspek ini.

d. Tahap Refleksi

Dari hasil pembelajaran siklus 2 maka dapat direfleksikan, yaitu:

1. Keaktifan belajar siswa mengalami peningkatan, akan tetapi masih ada aspek yang belum maksimal seperti bertanya dan presentasi di depan kelas

2. Pada pertemuan pertama baru sebagian yang berani bertanya atau berpendapat

3. Pada pertemuan berikutnya semakin banyak yang bertanya tanpa takut disalahkan

4. Pada soal yang menggunakan perhitungan masih ada sebagian siswa yang belum paham

5. Pembelajaran masih monoton dengan alur demonstrasi alat dan pertanyaan

6. Waktu untuk materi masih kurang Keterbatasan waktu penelitian

\section{Aspek Keberhasilan Tindakan}

Pelaksanaan penelitian tindakan kelas ini dilakukan dalam dua siklus, yaitu siklus I dilaksanakan dua pertemuan dan siklus II dilaksanakan tiga pertemuan. Hasil dari pelaksanaan penelitian ini untuk mengetahui peningkatan keaktifan dan hasil belajar IPA kelas VIII D tahun ajaran 2017/2018. Berikut ini merupakan gambaran dan pembahasan hasil penelitian yang dilakukan, yaitu:

\section{Keaktifan siswa}

Pelaksanaan tahap persiklus untuk melihat keaktifan hasil belajar yaitu membaca sumber belajar, bertanya, mendengarkan teman saat presentasi, menulis informasi penting narasumber dan mencatat hasil diskusi, bergerak dan berpindah tempat untuk membentuk kelompok, memecahkan masalah dalam kelompok serta berani tampil di depan kelas untuk melakukan presentasi, menjawab pertanyaan dan melakukan demonstrasi.

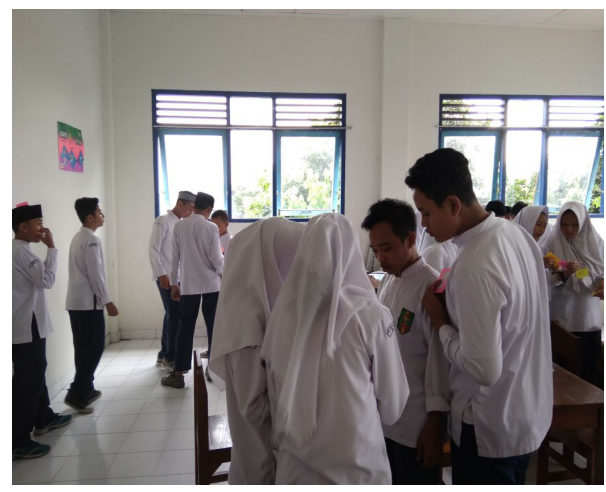

Gb.2 Siswa kelas VIII D mencari pasangan pada siklus I pertemuan pertama

Berikut adalah data rekapitulasi keaktifan siswa kelas $8 \mathrm{D}$ dalam pembelajaran sebelum dan sesudah menggunakan metode Index Card Match pada materi hukum Newton, Energi dan Usaha:

Tabel 1

Hasil Keaktifan Belajar Siswa

Persiklus

\begin{tabular}{|c|c|c|c|c|c|}
\hline \multirow{3}{*}{ Pra } & \multicolumn{4}{|c|}{ Metode Index Card Match } \\
\cline { 2 - 6 } & \multicolumn{2}{|c|}{ Siklus I } & \multicolumn{3}{|c|}{ Siklus II } \\
\cline { 2 - 5 } & 1 & 2 & 1 & 2 & 3 \\
\hline \multirow{2}{*}{$30,47 \%$} & $47,61 \%$ & $70,95 \%$ & $73,80 \%$ & $85,7 \%$ & $93,3 \%$ \\
\cline { 2 - 5 } & $59,28 \%$ & \multicolumn{3}{|c}{$84,26 \%$} \\
\hline
\end{tabular}

Dari tabel diatas dapat kita lihat adanya peningkatan keaktifan belajar 
siswa di mulai dari pra siklus 30,47 $\%$ yang memang masih menggunakan metode konvensional seperti ceramah dan diskusi kemudian diadakan pembelajaran dengan metode index card match siklus I pertemuan pertama sebesar $47,61 \%$, hal ini disebabkan siswa masih belum mengetahui aturan main dalam metode index card match dan guru masih mendominasi kegiatan pembelajaran. Pada siklus I pertemuan kedua terjadi peningkatan keaktifan belajar siswa sebesar 70,95\% hasil dari refleksi siklus I pertemuan pertama maka dilakukan perbaikan di pertemuan kedua ini seperti membaca sumber belajar, mencatat informasi penting, dan mendengarkan teman saat presentasi coba dimaksimalkan oleh penulis.

Hasil Siklus II Pertemuan pertama nilai keaktifan belajar siswa sebesar $73,80 \%$ yang berarti kenaikan tidak terlalu jauh dari siklus I pertemuan kedua hal ini disebabkan penulis belum mampu meningkatkan beberapa aspek seperti pemecahan masalah dalam kelompok yang ditandai dengan dapatnya pasangan yang benar disetiap pertemuan, karena hal ini juga tergantung pada materi yang dipelajari. Siklus II pertemuan kedua terdapat hasil keaktifan belajar siswa sebesar $85,7 \%$ dimana lebih baik dari pertemuan sebelumnya, karena pada pertemuan kedua ini siswa sudah lebih paham tentang metode pembelajaran index card match maka para siswa pun juga menjadi lebih bersemangat dan mencoba membenahi beberapa aspek penilaian keaktifan seperti mulai banyak siswa yang aktif menyampaikan pendapatnya setelah salah satu temannya melakukan demonstrasi mobil bertenaga balon di depan kelas. Hal ini sesuai dengan teori konstruktivistik dimana belajar tidak hanya menghafal tetapi proses mengkonstruksi pengetahuan melalui pengalaman. Pengetahuan akan bermakna manakala siswa menemukan dan membangun pemahamannya. Kemampuan guru untuk meyakinkan siswa agar tidak takut berpendapat meski itu salah dan semua di apresiasi. Kemudian dipertemuan ketiga siklus II terjadi peningkatan sebesar 93,3\% dimana hasil dari pertemuan kedua menjadi evaluasi untuk pembelajaran dipertemuan ketiga ini.

Pembelajaran menurut Gagne (dalam wina sanjaya:2009:2013) yang menyatakan bahwa "instruction is a set of even that effect learners in such a way that learning is facilitated " bahwa mengajar adalah bagian dari pembelajaran (instruction), dimana peran guru hanya sebagai fasilitator yakni merancang dan merangkai sumber dan fasilitas belajar yang tersedia agar dapat dimanfaatkan untuk proses pembelajaran. Hal ini sangat sesuai dengan pembelajaran dengan metode index card match dimana sebelumnya guru masih mendominasi pembelajaran pada siklus I, kemudian dengan adanya refleksi maka diadakan perbaikan perencanaan dan seting kegiatan lainnya disiklus kedua sehingga peran guru tidak terlalu dominan tetapi memberikan kesempatan sebesar-besarnya kepada siswa untuk mengeksplorasi 
dan mengelaborasi pembelajaran yang mereka lakukan.

Beberapa aspek penilaian keaktifan siswa coba untuk benar-benar dimaksimalkan potensinya seperti membaca sumber belajar, mencatat informasi penting, mendengarkan teman saat presentasi, berpindah tempat mencari pasangan, dan menemukan solusi dalam kelompoknya meski memang belum sempurna hasil keaktifan dalam pertemuan ketiga ini memang untuk beberapa aspek seperti mengemukakan pendapat dan melakukan presentasi adalah sebuah tantangan bagi penulis untuk memaksimalkannya. Setelah melihat hasil akhir pertemuan ketiga ini dan keterbatasan waktu penelitian maka penulis mencukupkan dan mengakhiri siklus karena sudah lebih dari harapan bahwa keaktifan siswa kelas VIII D SMP Muhammadiyah 1 Depok tahun 2017/2018 terjadi peningkatan pada pembelajaran IPA menggunakan metode Index Card Match. Peningkatan keaktifan belajar siswa tersebut dapat dilihat pada grafik berikut:

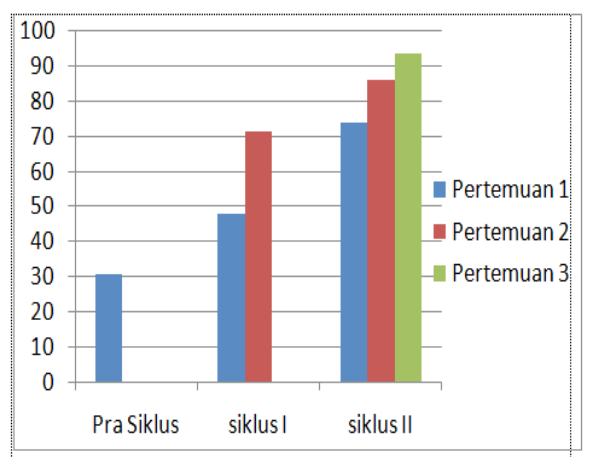

Grafik 1. Peningkatan Keaktifan Belajar Siswa

\section{Hasil Belajar}

Pada umumnya hasil belajar dapat dikelompokkan menjadi tiga ranah yaitu; kognitif, afektif dan psikomotorik, akan tetapi dalam penelitian ini peneliti melihat hasil belajar pada ranah kognitif. Pada ranah kognitif berhubungan erat dengan kemampuan berfikir, termasuk didalamnya kemampuan pada ranah pengetahuan, pemahaman dan penerapan. Berikut ini adalah hasil ulangan harian kelas VIII D persiklus, yaitu:

Tabel.2. Daftar Nilai Ulangan Harian

\begin{tabular}{|c|c|c|c|c|}
\hline \multirow[b]{2}{*}{ No } & \multirow[b]{2}{*}{ Nama Siswa } & \multirow[b]{2}{*}{ KKM } & \multicolumn{2}{|c|}{ Nilai } \\
\hline & & & $\begin{array}{c}\text { Siklus } \\
\text { I }\end{array}$ & $\begin{array}{c}\text { Siklus } \\
\text { II }\end{array}$ \\
\hline 1. & A1 & 75 & 64 & 76 \\
\hline 2. & A2 & 75 & 56 & 80 \\
\hline 3. & A3 & 75 & 84 & 84 \\
\hline 4. & A4 & 75 & 80 & 80 \\
\hline 5. & A5 & 75 & 64 & 64 \\
\hline 6. & A6 & 75 & 80 & 80 \\
\hline 7. & A7 & 75 & 80 & 84 \\
\hline 8. & A8 & 75 & 64 & 80 \\
\hline 9. & A9 & 75 & 80 & 92 \\
\hline 10. & A10 & 75 & 68 & 68 \\
\hline 11. & A11 & 75 & 64 & 80 \\
\hline 12. & A12 & 75 & 56 & 80 \\
\hline 13. & A13 & 75 & 64 & 56 \\
\hline 14. & A14 & 75 & 64 & 80 \\
\hline 15. & A15 & 75 & 84 & 80 \\
\hline 16. & A16 & 75 & 60 & 76 \\
\hline 17. & A17 & 75 & 64 & 56 \\
\hline 18. & A18 & 75 & 80 & 84 \\
\hline 19. & A19 & 75 & 60 & 80 \\
\hline 20. & A20 & 75 & 84 & 80 \\
\hline 21. & $\mathrm{~A} 21$ & 75 & 88 & 80 \\
\hline 22. & A22 & 75 & 60 & 64 \\
\hline
\end{tabular}


Amin Rosadi - Peningkatan Keaktifan dan Hasil Belajar Siswa dengan Metode Index Card Match ....

\begin{tabular}{|c|c|c|c|c|}
\hline \multirow{2}{*}{ No } & \multirow{2}{*}{ Nama Siswa } & \multirow{2}{*}{ KKM } & \multicolumn{2}{|c|}{ Nilai } \\
\cline { 4 - 5 } & & $\begin{array}{c}\text { Siklus } \\
\text { I }\end{array}$ & $\begin{array}{c}\text { Siklus } \\
\text { II }\end{array}$ \\
\hline 23. & A23 & 75 & 64 & 80 \\
\hline 24. & A24 & 75 & 60 & 80 \\
\hline 25. & A25 & 75 & 88 & 80 \\
\hline 26. & A26 & 75 & 92 & 84 \\
\hline 27. & A27 & 75 & 80 & 92 \\
\hline 28. & A28 & 75 & 80 & 76 \\
\hline 29. & A29 & 75 & 60 & 80 \\
\hline 30. & A30 & 75 & 76 & 80 \\
\hline
\end{tabular}

\section{Keterangan:}

\section{Siklus I}

Tuntas

: 14 siswa atau $46 \%$

Tidak tuntas

: 16 siswa atau $64 \%$

\section{Siklus II}

Tuntas : 25 siswa atau $83,3 \%$

Tidak tuntas : 5 siswa atau $16,7 \%$

Berdasarkan tabel ulangan persiklus diatas diketahui pada siklus pertama 14 siswa tuntas dan pada siklus kedua terdapat 25 siswa yang tuntas dengan presentase $46 \%$ siklus menjadi $83,3 \%$. Berdasarkan hal tersebut dapat disimpulkan bahwa terjadi peningkatan hasil belajar mata pembelajaran IPA menggunakan metode Index Card Match. Peningkaatan hasil belajar siswa tersebut dapat dilihat pada grafik berikut:

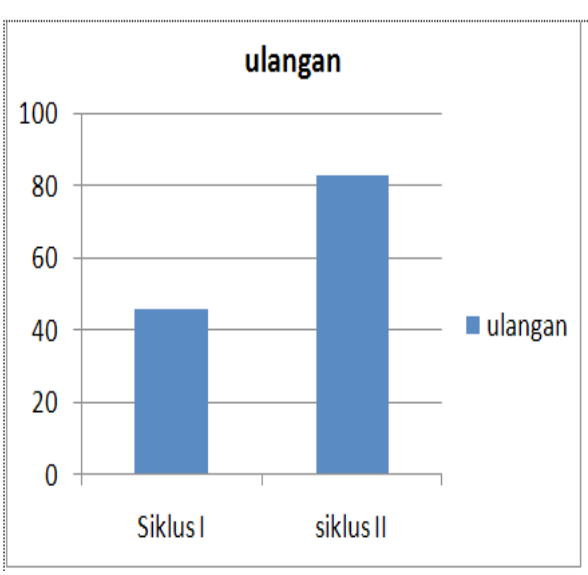

Grafik 2. Hasil Belajar Siswa

\section{KESIMPULAN}

Dari hasil penelitian dan pembahasan dapat disimpulkan bahwa metode pembelajaran Index Card Match dapat meningkatkan keaktifan dan hasil belajar siswa mata pelajaran IPA dengan materi Hukum Newton, Usaha dan energi yang dilaksanakan di kelas $8 \mathrm{D}$ SMP Muhammadiyah 1 Depok tahun ajaran 2017/2018. Keaktifan belajar siswa meningkat dari satu siklus ke siklus berikutnya, pra siklus $30,47 \%$ kemudian siklus I sebesar 59, $28 \%$ dan siklus II menjadi 84, $26 \%$ atau 25 dari 30 anak meningkat keaktifan belajar siswa yang meliputi aspek membaca sumber belajar, bertanya, mendengarkan teman saat presentasi, mencatat informasi penting, bergerak atau berpindah tempat, memecahkan masalah dalam kelompok, berani tampil didepan kelas untuk presentasi.

Hasil belajar juga mengalami peningkatan dari siklus I yang Tuntas 
sebesar $46 \%$ atau 14 dari 30 siswa dan di siklus II sebesar 83,3\% atau 25 dari 30 siswa kelas VIII D SMP Muhammadiyah 1 Depok.

Berdasarkan hasil tersebut dapat di simpulkan bahwa metode pembelajaran Index Card Match cukup efektif untuk dapat meningkatkan keaktifan belajar siswa dan peningkatan hasil belajar siswa kelas VIII D SMP Muhammadiyah 1 Depok tahun ajaran 2017/2018.

\section{DAFTAR PUSTAKA}

Arikunto, Suharsimi dan Cepi Safrudin Abdul Jabar. 2008. Evaluasi Program Pendidikan: Pedoman Teoritis Praktis bagi Mahasiswa dan Praktisi Pendidikan Edisi Kedua. Jakarta: Bumi Aksara.

Arikunto, Suharsimi. 2006. Prosedur Penelitian Suatu Pendekatan Praktek. Jakarta: Rineka Cipta. .2008. Penelitian

Tindakan Kelas. Edisi Revisi. Jakarta: Bumi Aksara. 2010. Dasar-

Dasar Evaluasi Pendidikan. Edisi Revisi. Jakarta: Bumi Aksara.

Budi Wibowo,Arif. 2015. Penerapan Metode Index Card Match Untuk Meningkatkan Hasil Belajar IPS Materi Gejala Alam Pada Siswa Kelas VI SD Negeri 1 Kedungpilang Kecamatan Wonosegoro Kabupaten Boyolali Tahun Pelajaran 2014/2015. Salatiga. Fak.Tarbiyah IAIN Salatiga

Depdiknas,2006. Panduan Pengembangan Pembelajaran IPA Terpadu Sekolah
Menengah Pertama dan Madrasah Tsanawiyah . Jakarta: Depdiknas. Haryati, Mimin.2008. Model Dan Tehnik Penilaian Dalam KTSP. Jakarta: Gaung Persada

Peraturan Menteri Pendidikan Nasional No 22 Tahun 2006

Rochiati Wiraatmadja.2005. Metode Penelitian Tindakan Kelas. Bandung: Remaja Rosda karya

Silberman, Mel.2009. Active Learning 101 Strategi Pembelajaran Aktif. Yogyakarta: Pustaka Insan madani Sanjaya, Wina. 2009. Kurikulum Dan Pembelajaran, Teori Dan Praktik Pengembangan Kurikulum Tingkat Satuan Pendidikan (KTSP).Jakarta: Kencana

Sardiman, AM, 1996. Interaksi dan Motivasi Belajar. Jakarta: Raja Grafindo Persada

Salim, Peter dan Yenny Salim, 1991. Kamus Bahasa Indonesia Kontemporer, Jakarta: Modern English Pers.

Sriyono dkk.1992. Teknik Belajar Mengajar dalam CBSA. Jakarta: PT Rineka Cipta

Sujiono, Anas, Pengantar Evaluasi Pendidikan, Jakarta: Pers, 2009

Wibowo, Widodo Setyo.2017. Menumbuhkan 21st century skills aspek learning and innovation skills-4cs siswa melalui pengembangan bahan ajar IPA berbasis model projectbased learning. Yogyakarta.FMIPA UNY

www.kemdikbud.go.id/pisaindonesia2016

www.puskur.net .Panduan Pengembangan IPA Terpadu 